\title{
The Research on the Reform of the Training Mode Of Electrical Automation In Colleges and Universities under the Background of the New Curriculum Reform in Shandong
}

\author{
Pengcheng Chen ${ }^{1, a}$ \\ ${ }^{1}$ School of Automation and Electrical Engineering, Linyi University, linyi, shandong, 276005, china \\ aemail: 765321088@qq.com
}

Keywords: Electrical Engineering And Automation; Cultivation of the Talents; Countermeasures

\begin{abstract}
With the development of science and technology in the society, the electrical engineering has accumulated the experience for more than 100 years, which provides the strong protection for the progress of human science and technology. The role of electrical engineering has been irreplaceable from the steam age to the electrical age. Although the study of electrical engineering has emerged late in China, its development potential is of great importance. This potential can be attributed to the continuous deepening of the electrical engineering and automation and the cultivation of professional and innovative talents. This paper aims to explore the methods of cultivating the innovative talents of electrical engineering and automation in Shandong province from different angles.
\end{abstract}

\section{Introduction}

The Chinese universities and colleges have established the specialty in the electrical engineering and automation in 1998. After several years' development, this specialty has cultivated amount of talents on the electrical engineering and automation for the development of the country. These talents play a significant role in all kinds of the enterprises. So far, this specialty has been almost universal in all domestic universities and colleges for science and technology. Faced with the rising employment pressure and problems occurred in the course study of college students, the talents training program is urgent in need of reform. The cultivation of innovative talents is of vital importance with the improvement of science and technology.

\section{Status and Problems in the Domestic Electrical Engineering and Automation}

At this stage, the electrical engineering and automation has advantages on the both the talents cultivation and the employment. The progress of science and the updated information technology have brought great opportunities to our colleges and universities. Therefore, the majority of colleges and universities has paid eough attention to the electrical engineering and automation. The talents cultivation in this specialty has become one of the most important teaching objectives.

At present, a number of domestic well-known universities such as Tsinghua University, Harbin Institute of Technology, Tianjin University, Zhejiang University etc. It can be seen that Chinese universities attach great importance to the talents training of the electrical engineering and automation. Since the beginning of the development in this specialty, the universities and colleges including this specialty have reached more than 200. It is a great opportunity for these schools to develop the electrical engineering and automation faster. At the same time, many problems exist in this specialty such as the inappropriate teaching method, the weak receiving ability of students, large employment pressure etc., which leads to a challenge nowadays. The principle "Advanced talents training to meet the requirements of the relevant system operation, communication, integrated automation, power electronics technology, information processing, experimental analysis, research and development, economic management and electronic computer technology applications etc.” is designated as the objectives of the majority of our colleges and universities. 
Many students in the universities and colleges of Shandong are unwilling to learn the theories on the basis of the feedback of teaching. Most students think that the classroom learning does not make sense to their work in future. Meanwhile, the teaching model of the electrical engineering and automation in many universities and colleges does appear the shortcomings. As is known to us, "theory combined with practice" help us do twice as fast with half the effort. An urgent need for reform in these schools will be applied to meet the requirements of the society for the innovative compound talents.

\section{Reform of Teaching Method and Improvement of Teaching Quality}

The electrical engineering and automation is one of the key subjects of schools for science and engineering. To some extent, The effect of the talent training in this specialty will affect the development of science and technology in China. This characteristic determines a higher level of requirements on the teaching methods of college teachers. Faced with the rapid development and change of society, the reform of teaching method is imperative.

3.1 The match of teaching materials and courses determines the basis of high-quality teaching.

In the teaching process of college, many people after graduation still do not know the contents of textbooks. This phenomenon shows to some extent the imperfect set of the teaching courses. "No lesion with textbooks" also means a waste of knowledge. Teaching materials are the basis of teaching. In the innovative talents training in the electrical engineering and automation, it is clear that teaching cannot be separated from teaching materials. Therefore, in the process of course setting, enough attention has to be paid to the match of the teaching plan and course, so that each student can get the comprehensive understandings for the knowledge.

3.2 The improvement of teaching management system determines the way to cultivate the innovative talents

The teaching management system of a university has a direct effect on the teaching quality in the universities and colleges. Effective standardized teaching management system also indirectly helps improve the teaching quality. Students should be trained and assessed in module to achieve "one practice with one test" in order to cultivate the innovative talents with "thick foundation, wide ideas, high ability, strong quality”.

3.3 The simple teaching form is broken to improve the quality of classroom teaching.

The traditional "teacher-oriented" teaching form in the teaching process should be broken by the college teachers in order to meet the requirements of cultivating "wide-ideas, innovative" talents. In the classroom, the interaction between teachers and students should be realized, and the multi-media teaching method should be used by teachers actively to stimulate students' interest so as to stimulate their innovative spirit.

\section{The practical courses are improved to stimulate students' innovation}

Practical teaching courses play an important role in electrical engineering and automation, which not only refers to the practice teaching, but also all aspects of practice improvements. It is useless to use the engineering disciplines that are not implemented or that are not fully implemented in practical teaching. In the process of cultivating talents in the electrical engineering and automation, the quality of cultivating talents in colleges and universities has a great relationship with its practice courses. Combined with the present practice teaching, the proposals are as follows:

1) To strengthen the main courses and laboratory with the combination of practical innovation, so that students in the experiments obtain the profound understanding of the course;

2) To pay enough attention to the electrical industry in the advanced equipment and the practical application, so that practical courses to keep up with the pace of modern technology development;

3) To strengthen the course setting in the practice of teaching, so that students can understand the course in the practice application. To play a mentor role and provide complete professional courses linked to the students' innovative practice;

4) To encourage students to participate in the internship activities of the school-workplace. 
Actual work should be applied to exercise students' work ability so as to stimulate their spirit of innovation and laid the foundation with the employer's "zero docking” after their graduation.

\section{Conclusions}

This paper analyzes the status of the electrical engineering and automation in Shandong province, and discuss in detail a number of reform and innovation methods that can be carried out to cultivate innovative compound talents in the universities and colleges. These schools in the teaching process should be in accordance with the principle "improve the teaching courses and strengthen the practice" to train the students in the electrical engineering and automation, in order to meet the requirements of the innovative talents. The students in the electrical engineering and automation should concentrate on their overall quality from various aspects to meet the requirements of high-quality, diversified and innovative talents.

\section{References}

[1] Li C. Research on the Inter-Disciplinary Talents Training Mode of Local Normal Universities in the Background of the New Curriculum Reform[J]. Journal of Mianyang Normal University, 2013.

[2] Zhang W H, Sun C G. Analysis on the Ways of University English Teachers'Professional Development under the Background of New Curriculum Reform[J]. Foreign Language Research, 2010.

[3] Liu Y. The Practical Research of Provincial Teaching Research Activity Mode under the Background of New Curriculum Reform[J]. Journal of Heilongjiang College of Education, 2015.

[4] Xuan S, Liu W. The Change of Physics Teacher's Classroom Teaching Behavior in Middle School Under the New Curriculum Reform Background[J]. Journal of Shandong Education Institute, 2004.

[5] Jian-Sheng Y U, Zhang A H. The Discussion of History Teaching and Assessment Mode in High School under the Background of the New Curriculum Reform[J]. Journal of Qingdao Technical College, 2010. 